\title{
Protest activity of youth in Yekaterinburg in 2017-2021: cases and determining factors
}

\author{
Alexander Vatoropin*, Sergey Vatoropin, Natalya Chevtaeva \\ Ural Institute of Management - Branch of the Russian Academy of National Economy and Public \\ Administration under the President of the Russian Federation, Yekaterinburg, Russia
}

\begin{abstract}
The article examines the political and social protest activity of Yekaterinburg youth in 2017-2021. The protest performances of youth in the framework of all-Russian protest actions and actions, conditioned by the local socio-political agenda, are analyzed. The external and internal factors of activating the protest potential of youth and its transformation into street actions are characterized. Based on the analysis of resonant cases and a secondary analysis of the results of sociological research conducted among the youth of Yekaterinburg in 2017-2021, the most significant factors in activating the protest potential are identified. The conclusion is made about the formation of a certain political culture in the youth urban environment while maintaining predominantly passive (conventional) forms of protest activity, primarily on the Internet.
\end{abstract}

\section{Introduction}

Young people are traditionally a social base for the formation of protest movements. Foreign and domestic experience testifies that it is young people who combine the ability for quick mobilization, serious intellectual and value potential and youthful maximalism, who are not only able to defend their rights and legitimate interests during street protests, but also to a greater extent to implement radical protest practices, create momentum for large-scale revolutionary movements.

The turbulent development of modern society, combined with a crisis of moral values, growing socio-economic problems, including in the context of the coronavirus pandemic, create objective, external prerequisites for the growth of protest potential in the youth environment and its transformation into street protest activity. At the same time, the greatest protest potential, as a rule, is demonstrated by young people in large cities, who have the widest opportunities for consolidation on the basis of a common, similar life experience and modern means of communication. Within the framework of this article, we will consider the protest activity of young people in one of the largest Russian cities - Yekaterinburg in 20172021, resonant cases of protest actions and factors contributing to the activation of protest potential.

\footnotetext{
* Corresponding author: vatoropin-as@,ranepa.ru
} 


\section{Research methodology}

The protest activity of youth in Yekaterinburg is analyzed on the basis of statistical data from the All-Russian Center for the Study of Public Opinion and the Public Opinion Foundation, monitoring and reports on the protest activity of the population in 2017-2021, and media materials. Cases of protest activity of youth in Yekaterinburg, factors that determine the growth of protest potential and the transformation of protest moods into street actions, are considered on the basis of a secondary analysis of the results of sociological research conducted among youth in Yekaterinburg in 2017-2021.

\section{Research results and discussion of the results}

We will begin our analysis of the protest activity of young people in Yekaterinburg by examining the performances in the framework of the All-Russian protest actions. Exactly 2017-2018 were marked, on the one hand, by the intensification of social protest, on the other, by all-Russian anti-corruption actions with political slogans, up to the resignation of top officials of the state, and protests against the results of federal elections. Note that both those and other actions on a national scale found some support among the residents of Yekaterinburg in general and young people in particular.

A sharp increase in social protest activity in Russia in 2017-2018 (if in the last three months of 2017 the total number of shares in this direction was 372, then in 3 quarter of 2018 it was 3.5 times more - 1244) was mainly due to dissatisfaction with the results of the pension reform (46.5\% of all shares) [1]. It should be noted that among the participants of the actions, the largest of which took place in July - September 2018, young people who were in solidarity with citizens of retirement and pre-retirement age played a significant role. At the same time, the extremely topical nature of the problem that worries tens of millions of Russian citizens, the sharp increase in the number of protest demonstrations did not cause either the radicalization of the protests or their significant scale in Russian cities. If the actions against the pension reform in Novosibirsk and Barnaul, which received wide coverage in the media in the summer of 2018, gathered just over 2 thousand people, then, for example, environmental protests in the Arkhangelsk region against the construction of a landfill - up to 8 thousand participants (according to official data, according to organizers of actions - 30 thousand) [2]. The relatively small scale and degree of radicalism of actions against the pension reform were also recorded in Yekaterinburg. Thus, the most numerous protest on July 28, 2018, which gathered about 5 thousand participants, among whom, according to various estimates, there were 20 to $40 \%$ of young people, lasted less than an hour, and the main forms of protest activity were applause support of the speaking representatives of opposition political movements (first of all, the regional branch of the Communist Party) and signatures for the abolition of the pension reform [3].

If the problems of a social orientation, as practice shows, affect a significant part of the population and have the potential to activate the mass protest movement, then the actual political issues in recent years are rarely catalysts for activating a mass street protest. A significant role in reducing political protest activity is played by the strengthening of opposition to such manifestations on the part of the state: 1) after the actions of 2011 against the results of the elections to the State Duma of the Russian Federation, the consistent introduction of new regulatory and administrative barriers to the coordination of political protest actions is noted, 2) in contrast to actions with a pronounced social protest agenda, speeches under political slogans (especially not agreed with the authorities) meet with a harsh reaction from law enforcement agencies, 3) the result of such actions for protesters is often mass arrests, administrative and criminal liability, 4) extremely low probability satisfying the requirements put forward. 
In this regard, it is not surprising that against the background of all-Russian protests against raising the retirement age and resonant environmental protests in 2017-2018, anticorruption actions "He's not Dimon for you" demanding the resignation of the then Prime Minister of the Russian Federation D.A. Medvedev in 2017 and protests against the results of the presidential elections in the Russian Federation in 2018 gathered a relatively small number of participants even in Moscow - 7.5 thousand and 1.5 thousand participants, respectively [4]. In Yekaterinburg, the action "He's not Dimon for you" on March 26, 2017, gathered, according to the organizers, up to 3 thousand participants, which is more than in other major cities of Russia (with the exception of Moscow and St. Petersburg). Despite the fact that the media published data on detentions, including of young people, the very nature of the actions was predominantly peaceful, and the reaction of the police officers was restrained. Nevertheless, the use of "tactics of targeted detentions" by law enforcement agencies, along with reports of students dropping out of universities who took part in unauthorized demonstrations, largely prevented further radicalization of protest activity in the urban youth environment [5]. Only 1 person was detained at an uncoordinated protest against the results of the presidential elections on May 5, 2018 [6].

In general, the youth of Yekaterinburg in the period under review, as the results of the research of Y.I. Solomatina "Features of the political orientations of Yekaterinburg youth and their dynamics in 2015-2018" [7], characterized by:

1) a fragmentary interest in political life, predominant attention to individual political events, rather than an overall high degree of political participation;

2) significant eclecticism of political thinking and political practices (for example, a combination of a negative assessment of the activities of federal authorities and a positive assessment of the activities of the President of the Russian Federation, prevailing support for liberal political and ideological values and a willingness to vote for representatives of the conservative wing of the political spectrum in elections, etc.);

3) reduced political and electoral activity;

4) a general critical attitude towards political and social institutions of modern Russia, regional and local authorities;

5) broad activity in the discussion of political events, first of all, on the Internet.

Based on the above characteristics, it can be stated that in the presence of a number of prerequisites for activating the protest potential, the mobilization and consolidation of the mass youth protest movement with political demands in Yekaterinburg is difficult.

The aforementioned fragmentary interest in certain resonant political events can cause a short-term growth of street protest political activity among the youth of Yekaterinburg. So, in January 2021, the events concerning the opposition politician A.A. Navalny (deterioration of his health, treatment in foreign clinics, return to Russia, arrest, etc.) against the backdrop of an all-Russian action under the slogan "Freedom to Navalny!" formed the basis for urban protests. So, on January 23, 2021, a fairly large-scale rally and procession, not coordinated with the authorities, in support of the opposition took place, and gathered 3 thousand participants (according to official data, according to the organizers - 10 thousand). However, the predictably harsh reaction from the authorities (squeezing protesters from the site for an uncoordinated rally, arresting dozens of participants, and subsequent initiation of administrative and criminal cases) did not radicalize the protests [8]. If in the winter and spring of 2021 repeated actions often gathered thousands of participants and proceeded according to a similar scenario, by the summer the protest activity was minimized. Moreover, the surge of protest potential (primarily youth), along with systemic opposition to the organization and conduct of actions by the state, led to practically zero protest activity after the elections to the State Duma of the Russian Federation. The mass picket on September 25, 2021 in Yekaterinburg gathered only about 200 participants, while a significant part of them 
were representatives of local and regional branches of the opposition political parties, the Communist Party of the Russian Federation and Yabloko [9].

Along with support for all-Russian demonstrations, it is worth highlighting the protest actions of the residents of Yekaterinburg, the reason for which was the internal, city agenda. In this case, the most resonant action was against the construction of a temple in the city square. During the week from May 13, 2019, up to 5 thousand people gathered at the site near the Drama Theater every evening. Despite the predominantly peaceful nature of the demonstrations, law enforcement agencies detained several dozen people, most of whom were young people aged 23-28 [10], 4 participants of the protests were convicted under Article 212 of the Criminal Code of the Russian Federation for organizing mass riots [11].

Analyzing the genesis of protest activity in the course of the actions under consideration, it should be noted that it differs significantly from other resonant speeches in Russia, conditioned by the local agenda. If the protests in Shies against the construction of a landfill in 2019 and in Kuzbass against the construction of a coal loading station in 2020, which also received wide media coverage and reaction from both regional and federal authorities [12], were aimed at preserving the environment and, ultimately, the health of local residents, the "battle for the square" in Yekaterinburg can be attributed to civil protest actions not directly related to the satisfaction of basic security needs. D.V. Rudenkin, in his study "Growth impulses of protest activity of Russian youth: the case of Yekaterinburg" [13], notes several features of protest moods among young people that precede street actions.

First of all, it should be noted a high degree of dissatisfaction with the general situation in Russia, a significant gap between desired and existing social values. Thus, $80 \%$ of young people noted injustice as a key attribute of existing social relations, about half of the respondents stated a consistent increase in social injustice. Two-thirds of young people stressed that the existing realities "do not correspond to their ideas about the ideal". At the same time, the largest gap between existing and ideal values was noted in such important categories as human rights ( $6 \%$ versus $71 \%$ ), morality (4\% versus $51 \%$ ), freedom $(10 \%$ versus $60 \%$ in the current Russian and ideal society, respectively).

Second, the researcher's correlation analysis between the socio-demographic characteristics of young people and their willingness to participate in protest actions did not reveal clear interdependencies. Factors such as gender, age, area of residence, financial situation did not have a statistically significant effect on the respondents' expectations regarding the holding of street protests in the city, and on their willingness to take direct part in them. The only significant factor identified as a result of the correlation analysis was the general attitude towards Russian society as unfair, the discrepancy between existing and desired values.

Third, a characteristic feature of street protest actions was the absence of a preceding burst of social tension and protest sentiments recorded in the framework of sociological research. Thus, the level of expectations of protest actions and the willingness to take part in them among the youth of Yekaterinburg not only did not exceed, but even was $4 \%$ lower than the all-Russian indicators of protest potential published by WCIOM [14] and FOM [15] (25\% of Yekaterinburg youth expected protests and $23 \%$ expressed their readiness in them participate against $29 \%$ and $27 \%$ at the all-Russian level, respectively).

Summing up the analysis, A.V. Rudenkin, in our opinion, rightly notes that the sources of the activation of the protest potential of Yekaterinburg youth should be sought not only in the "traditionally" considered by researchers reasons - shortcomings in the implementation of state youth policy, shortcomings in the system of civic education or the destructive influence of foreign and domestic protest provocateurs [16, 17, 18]. An important factor is "the inner experiences of young people, the formation of a special political culture in many of them, which increases their demands on society and creates the basis for the growth of their dissatisfaction with the surrounding conditions of life" [13]. 
Let us analyze the results of the "battle for the square" and its influence on protest moods among the youth of Yekaterinburg. First, we note that the demands of the protesters were met by the authorities, which is generally not typical for most protest actions in modern Russia. Such a reaction on the part of the state was due to several factors at once: 1) a hardto-predict outburst of protest potential, which complicates the implementation of standard preventive anti-protest measures, 2) a pronounced social agenda in the absence of radical political slogans, the predominantly peaceful nature of speeches, 3) public resonance caused by actions. One way or another, the local protest agenda received a response from not only regional, but also federal authorities.

Secondly, the subsequent reaction of both the protesters themselves and the residents of Yekaterinburg in general to the satisfaction of the demands put forward is ambiguous. On the one hand, active participants in the events spoke positively both about the civic position of the protesters who defended the square, and about the meaning of the event, which "shook the city, showed that the townspeople are subjects of city life, that they are ready, have the right and deserve to take part. in the development of urban solutions" [19]. On the other hand, meeting the demands of the protesters, most of whom were young people, did not have a significant impact on the overall transformation of protest moods in the youth environment of Yekaterinburg. Moreover, even the result of the action, which was positive for the participants, did not lead to significant changes in attitudes towards the effectiveness of this form of defending their own rights, legitimate interests, and beliefs.

So, according to the research of V.A. Franz "Peculiarities of the spread of protest sentiments among Russian urban youth in the information society (on the example of Yekaterinburg)" [20], the largest number of young city residents (33\%) continues to be sure that there are no effective forms of protest activity in Russia in principle. Despite the positive results of the "battle for the square" actions, only $27 \%$ of the respondents note the effectiveness of such forms of street protest activity. A little less - $24 \%$ of young people believe that the greatest effect is provided by posts and videos on the Internet (social networks). Less than $20 \%$ of respondents expressed their readiness to take personal part in street protests, if necessary, to draw public attention to an acute social problem. At the same time, $44 \%$ would limit themselves to relevant publications in the Internet space, $40 \%$ would ignore the elections, would not participate in political life in general, and about $30 \%$ would not react at all even to acute social problems. One way or another, street protest activity has not become a widespread practice among the youth of Yekaterinburg, and a significant degree of disagreement with the existing realities of Russian society, even with the formation of a certain political culture, does not lead to the radicalization of protest sentiments. The Internet remains mainly not a means of organizing and coordinating street protest activity, but a means for splashing out the protest potential of the youth of the city of Yekaterinburg.

\section{Conclusions}

Yekaterinburg is traditionally considered a city with a relatively high protest potential relative to most other large Russian cities, and protest sentiments are quite widespread among the youth of Yekaterinburg. The cases of protest activity we have considered and the results of sociological research fully confirm this thesis: young residents of the city take part in all the largest all-Russian protest actions, and the example of an action in defense of the square in 2019 generally seems to be a unique protest case for modern Russia. In our opinion, it is really possible to speak about the gradual formation in the youth environment of a culture of active protection of their own views and values. At the same time, the analysis showed, in general, the absence of integral political convictions, the eclecticism of political consciousness, the willingness to take part in street performances mainly from time to time without preconditions for the formation of a stable protest movement. Conventional 
(peaceful) forms of protest activity dominate among the youth, and the Internet and social networks remain the main platform for expressing protest views.

\section{Acknowledgments}

The reported study was funded by RFBR and EISR, project number № 21-011-31682.

\section{References}

1. Growth of protest activity in Russia: the results of the all-Russian monitoring of 20172018, Center for Economic and Political Reforms (2021). Access mode: https://orenday.ru/assets/files/protesty-v-rf-vserossijskij-monitoring.pdf

2. Why Arkhangelsk opposed the Moscow garbage, Vedomosti (2021). Access mode: https://www.vedomosti.ru/opinion/articles/2018/12/10/788816-arhangelsk-protiv

3. "We will not live to 65!": In Yekaterinburg, a rally against the pension reform gathered about 5 thousand people, Komsomolskaya Pravda (2021). Access mode: https://www.ural.kp.ru/daily/26861.5/3903555/

4. Ministry of Internal Affairs of the Russian Federation: official site (2021). Access mode: http://мвд.pф

5. He's not Dimon for you. Protest meeting in Yekaterinburg: how it was, Revda-Info.ru (2021). Access mode: https://www.revda-info.ru/2017/03/26/on-vam-ne-dimonprotestnyj-miting-V-ekaterinburge-kak-eto-bylo/

6. The protester could not stop, Kommersant. Access mode: https://www.kommersant.ru/doc/3622308

7. Y. I. Solomatin, Features of the political orientations of Yekaterinburg youth and their dynamics in 2015-2018, XXII International Conference in memory of Professor L. N. Kogan "Culture, personality, society in the modern world: methodology, experience of empirical research.", 1436 - 1446 (2019)

8. 14 people were detained at a protest in Yekaterinburg, e1.ru (2021). Access mode: https://www.e1.ru/text/politics/2021/01/23/69720066/

9. "We won, hence the depression in the Kremlin", Znak.com (2021). Access mode: https://www.znak.com/2021-09-

25/v_ekaterinburge na akciyu_kprf_protiv_itogov_vyborov_prishli_okolo_200 chelo vek

10. Opponents of the temple settle in the park, Kommersant (2021). Access mode: https://www.kommersant.ru/doc/3968897

11. The court considered the last of the investigated cases of protests in the park near the Drama Theater, Znak.com (2019). Access mode: https:/www.znak.com/2019-1204/sud rassmotrel poslednee iz rassledovannyh del_o protestah_v skvere u teatra dramy

12. They forced the authorities to listen: 4 protests in Russia, which gave a result (2020). Access mode: https://www.nn.ru/text/world/2020/08/21/69434755/

13. D. V. Rudenkin, Growth impulses of protest activity of Russian youth: the case of Yekaterinburg, Conflict Studies / nota bene, 1, 1 - 14 (2020)

14. Protest potential, Official site of the All-Russian Center for the Study of Public Opinion (2021). Access mode: https://wciom.ru/index.php?id=177 
15. Protest moods, Official site of the Public Opinion Foundation (2021). Access mode: https://fom.ru/obshchestvo/11090

16. G. I. Avtsinova, M. A. Burda, Youth policy of modern Russia: absenteeism and political protest, Questions of political science, 4 (44), 649 - 655 (2019)

17. T. V. Bolshunova, The value-motivational aspect of the participation of "generation $z^{\prime \prime}$ in the modern political process, Bulletin of the Voronezh State University. Series: History. Political science. Sociology, 1, 63 - 67 (2018)

18. E. I. Kovtun, Specificity of modern youth protest movements, Questions of political science, 4 (44), 712 - 721 (2019)

19. "Square" is a year, How today the main participants in the events remember standing on the Drama, el.ru (2020). Access mode: https://www.e1.ru/text/gorod/2020/05/13/69255265/

20. A. V. Franz, Features of the spread of protest sentiments among Russian urban youth in the information society (on the example of Yekaterinburg), Philosophy and human sciences in the information society, 3, $61-80$ (2020) 